\title{
Application of the SERVQUAL Model for the Evaluation of the Service Quality in Moroccan Higher Education: Public Engineering School as a Case Study
}

\author{
Ouissal GOUMAIRI ${ }^{1}$, Es-Saâdia AOULA $^{1}$ \& Souad BEN SOUDA ${ }^{1}$ \\ ${ }^{1}$ Laboratory of Signals, Distributed Systems and Artificial Intelligence, ENSET Mohammedia, University Hassan II \\ of Casablanca, Morocco \\ Correspondence: Ouissal GOUMAIRI, Laboratory of Signals, Distributed Systems and Artificial Intelligence, \\ ENSET Mohammedia, University Hassan II of Casablanca, Morocco.
}

Received: June 1, 2020

Accepted: July 28, 2020

Online Published: July 29, 2020

doi:10.5430/ijhe.v9n5p223

URL: https://doi.org/10.5430/ijhe.v9n5p223

\begin{abstract}
The quality of higher education systems currently represents a major challenge for the development of societies. In Morocco, engineering education is at the heart of this development, it is a major and necessary lever which, due to an increasingly demanding job market, faces several challenges. According to Moroccan Directorate for Strategies and Information Systems (2018) these challenges are classified into two categories: quantitative (low rate of Moroccan engineers compared to global figures; 1.57 graduates in engineering per 10,000 inhabitants in 2016) and qualitative (adaptation of the academic curriculum to the needs of the job market). However, little work has been done on the introduction of service assessment tools in higher education in Morocco (Akrim, Figari, Mottier-Lopez, \& Talbi, 2010).

In our article, we are interested in the SERVQUAL method (SERVice QUALity-Quality of Service). This approach, initially designed to measure customer satisfaction in a company, allows, when applied to higher education, to measure student satisfaction at the university. Based on a bibliographic research, we have identified the five dimensions of the model that impact the quality of service.

Through the application of this model to a sample of students from a public engineering school, we have been able to determine that tangible elements and physical installations have the biggest impact on service quality with a negative quality gap (-2.0275). As a result, more efforts are needed in these dimensions to improve service quality.

In conclusion, the SERVQUAL model, applied to the educational system and more precisely higher education, allows to quantify the non-quality by measuring the gap between the perception of the students and their expectations for a good service. It has the advantage of helping decision-makers take corrective actions needed to improve the service quality provided by universities as a part of a process of continuous improvement to achieve higher degree of excellence.
\end{abstract}

Keywords: quality, higher education, SERVQUAL, engineering education, service evaluation

\section{Introduction}

Continuous improvement of service quality and sustainable development of higher educational institutions remain at the heart of any progress and/or development of any society. In other words, all higher educational institutions are invited to identify their stakeholders and manage their requests and interests in order to assess their role in society and to evaluate their service quality (Đonlagić \& Fazlić, 2015). However, defining stakeholders (clients) for universities is more difficult than defining clients in industry: students, government, academic staff, businesses, students' families and society are all different clients for the educational system (Abdullah, 2006)

Students' role as stakeholder is essential in higher education. Therefore several European standards and guidelines for quality assurance require students to be involved in quality management and internal quality assurance processes in higher education institutions as equal partners (Leisyte et al., 2008).

Today, student satisfaction, particularly in terms of service, is a major challenge for universities. Given that the higher education sector faces strategic and economic challenges, namely accumulated competition and excellence in terms of quality of service (Felix, 2017; Kawshalya, 2016.). Consequently, providing an excellent service has 
become an important pillar for the development of higher education systems and their success (Saravanan,2018; Ali et al., 2016)

\section{Methodology}

In this paper, we have applied the SERVQUAL model which was first designed to measure the gap in customer satisfaction levels in the business world. It is among the recognized models in the field of service quality assessment.

Initially developed by Parasuraman (Parasuraman, Zeithaml \& Berry, 1985), this model addresses five dimensions which are general. These may be applicable to different categories of services (Mauri et al., 2013). Based on the bibliography (Datta \& Vardhan, 2017; Đonlagić \& Fazlić, 2015; Green, 2014). We have adapted these five dimensions to services offered by a Moroccan engineering school.

- Tangibles: they include physical goods, tools and facilities for practical work/tutorials and courses for engineers;

- Reliability: this is precision in terms of services;

- Responsiveness: it expresses the speed of providing a service to engineering students and the desire to help them;

- Assurance: it reflects the ability of engineering school staff to inspire confidence and reassure;

- Empathy: it is the care and attention given to each engineering student.

The objective of this model is to compare the expected service quality with that perceived by the engineering student (customer).

In order to assess the quality of the services, the difference $Q$ is formulated as follows:

$\mathrm{Q}($ quality of service $)=\mathrm{P}($ perceived service $)-\mathrm{E}($ expected service $)$

Based on a bibliographic study (Đonlagić \& Fazlić, 2015) we have developed the five dimensions into subcategories which are adapted to our case study as shown in the flowchart :

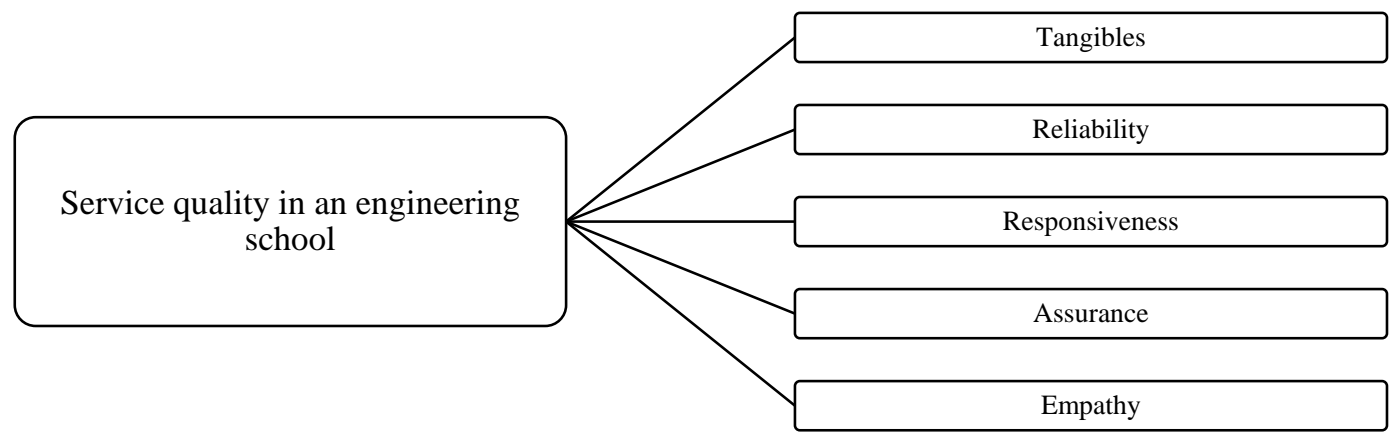

Figure 1. conceptual model of service quality for our case study according to the model of Parasuraman

(Parasuraman, Berry \& Zeithaml, 1991)

We have calculated the service quality from equation (1) applied to the elements of each dimension and we have determined the most critical dimension, which has the largest average of the service quality gap. We must focus our efforts on this critical dimension in order to close the gap in service quality.

\section{Literature Review}

The international state of the art offers a multitude of cases of application of the SERVQUAL model. These case studies are different in several areas, particularly in terms of student specialty and in terms of results found.

In South Africa, Greena adapted the SERVQUAL model to students at the Durban University of Technology (DUT). This study was carried out with 280 people. The results reveal that on average the students were dissatisfied. The most negative difference corresponded to the dimension of physical and school services. This indicates that the DUT must provide complete and modern laboratories (Green, 2014)The same result was found in two other studies, one in Morocco and the other in Thailand.

For the case study conducted in Moroccan higher education institutions (Cherqaoui et al., 2015.), only the impact of three variables is considered: tangible elements, reliability and assurance on student satisfaction. The study was carried out on a sample of 97 students. It demonstrates the need for suitable facilities and modern equipment in university establishments. 
As for the case study carried out in Thailand on the quality of service in higher education, (Yousapronpaiboon, 2014)the author examines the five dimensions of the SERVQUAL model. The study was conducted on a total number of 350 students from a private university. It revealed that the most critical dimension is tangibles, hence the importance of facilities and equipment in order to reduce service quality gap.

In addition, a study in the United Arab Emirates (UAE) with 300 students, examined the five dimensions of the SERVQUAL model at seven different campus universities in the UAE (Datta \& Vardhan, 2017). The main results revealed that services with higher quality difference fall under assurance. This result reflects the students' high expectations in terms of assurance.

In Bosnia and Herzegovina an article deals with the case of a sample of 73 students from the university of economics (Đonlagić \& Fazlić, 2015) using the SERVQUAL model. Statistical analysis has shown that the most negative gap concerns the dimension of empathy which is linked to the staff's interest in student success, help and support. The second negative difference relates to the reactivity linked to the response to student's needs. These two critical dimensions relate to staff behavior towards students. This highlights the need for the university to invest more effort in the education and training of its staff.

\section{Case Study: Moroccan Engineering School}

In our study, we assumed that the five dimensions of the model had an impact on the satisfaction of engineering students (Parasuraman, et al.,1985)

From the flowchart in Figure 1, we administered our questionnaire. Each question (item) corresponds to a sub-category. Our questionnaire contains 25 questions related to student expectations and 25 other questions to measure their perception of the service. All five dimensions of the SERVQUAL model: tangibles, reliability, responsiveness, assurance and empathy were covered by theses 25 questions. The structure of the questionnaire is presented in Table 1, below:

Table 1. Questionnaire structure

\begin{tabular}{ll}
\hline Dimensions & Number of items \\
\hline Tangibles & $1-4$ \\
Reliability & $5-10$ \\
Responsiveness & $11-13$ \\
Assurance & $14-19$ \\
Empathy & $20-25$
\end{tabular}

The dimension relating to tangibles includes questions 1 to 4 ; it is linked to material goods (for example equipment, teaching materials, IT materials, etc.). The dimension related to reliability is represented by questions 5 to 10 ; it is related to the ability to provide the promised service with precision and reliability (for example, to resolve student problems, complaints and requests). The third dimension (responsiveness) includes questions 11 to 13 and analyzes the attention paid to engineering students in order to provide a good and prompt service. The assurance dimension via questions 14 to 19 analyzes the behavior of non-university staff and their ability to convey confidence. And finally, the last dimension of this model (empathy) includes questions 20 to 25 and is related to the individualized attention and care that is provided to students. In this research, a 5-point Likert scale was used. In the original SERVQUAL model, the Likert scale is 7 points. Some researchers who have adapted the SERVQUAL model for higher education use a 5-point Likert scale. (Đonlagić \& Fazlić, 2015)

In statistical analysis, a sample with a sampling rate greater than $5 \%$ is considered to be a fairly large sample. For this research, our random sample's rate is $8 \%$ and the total number of students is $\mathrm{N}=53$.

The questionnaire was prepared in digital form (Google Forms) and then sent to the database grouping the email addresses of random students. The responses were combined into an Excel sheet for statistical analysis. The latter was performed on IBM SPSS version 21.

To assess the homogeneity and internal consistency of our questionnaire, the Cronbach's coefficient was calculated.

Table 2. Cronbach's alpha

\begin{tabular}{ll}
\hline Cronbach's alpha & Nb of Items \\
\hline $\mathbf{0 , 9 5 6}$ & 50 \\
\hline
\end{tabular}


The Cronbach's Alpha coefficient is 0.956 . It is therefore greater than 0.6 which means good internal consistency.

\section{Results and Discussion}

The table below groups the means of the different responses:

Table 3. Average responses

\begin{tabular}{|c|c|c|c|c|}
\hline Dimensions & Items & $(\mathbf{E})$ & (P) & $\mathbf{P}-\mathbf{E}$ \\
\hline \multirow[t]{4}{*}{ Tangibles } & 1. Equipment for conferences & 4.25 & 2.45 & -1.80 \\
\hline & 2. Materials for workshops & 4.72 & 2.43 & -2.29 \\
\hline & 3. Educational support & 4.51 & 2.79 & -1.72 \\
\hline & 4. School buildings and infrastructures & 4.45 & 2.15 & -2.30 \\
\hline \multirow[t]{6}{*}{ Reliability } & 5. Respect of the conference calendar & 4.38 & 2.85 & -1.53 \\
\hline & 6. Availability of tuition office & 4.62 & 2.53 & -2.09 \\
\hline & 7. Help and support for students & 4.68 & 2.74 & -1.94 \\
\hline & 8. Accurate planning of students' activities & 4.02 & 3.00 & -1.02 \\
\hline & 9. Consistent rating criteria & 4.38 & 3.04 & -1.34 \\
\hline & $\begin{array}{l}\text { 10. Useful time for carrying out certain } \\
\text { activities }\end{array}$ & 4.55 & 3.23 & -1.32 \\
\hline \multirow[t]{3}{*}{ Responsiveness } & 11. Deadlines for processing requests & 4.53 & 2.36 & -2.17 \\
\hline & $\begin{array}{l}\text { 12. Academic staff respecting students' } \\
\text { interests }\end{array}$ & 4.53 & 2.74 & -1.79 \\
\hline & $\begin{array}{l}\text { 13. Special attention and help students to } \\
\text { solve their problems }\end{array}$ & 4.40 & 2.68 & -1.72 \\
\hline \multirow[t]{6}{*}{ Assurance } & $\begin{array}{l}\text { 14. Academic staff have the necessary } \\
\text { knowledge and skills, as well as the } \\
\text { appropriate communication skills }\end{array}$ & 4.72 & 3.08 & -1.64 \\
\hline & 15. Study programs & 4.72 & 3.02 & -1.70 \\
\hline & 16. High level of education & 4.47 & 2.83 & -1.64 \\
\hline & 17. Staff reassures students & 4.17 & 2.70 & -1.47 \\
\hline & 18. Easy access to school & 4.26 & 2.62 & -1.64 \\
\hline & $\begin{array}{l}\text { 19. Professional answers to student } \\
\text { questions }\end{array}$ & 4.58 & 2.89 & -1.69 \\
\hline \multirow[t]{6}{*}{ Empathy } & 20. Understanding the needs of students & 4.60 & 2.66 & -1.94 \\
\hline & 21. Positive attitude towards students & 4.55 & 2.91 & -1.64 \\
\hline & $\begin{array}{l}\text { 22. Academic staff treat students fairly and } \\
\text { with respect }\end{array}$ & 4.70 & 2.87 & -1.83 \\
\hline & 23. Opening to students & 4.60 & 2.87 & -1.73 \\
\hline & $\begin{array}{l}\text { 24. Involvement of students for process } \\
\text { improvement }\end{array}$ & 4.75 & 2.17 & -2.58 \\
\hline & $\begin{array}{l}\text { 25. Respectful, kind and professional staff in } \\
\text { communication with students }\end{array}$ & 4.51 & 2.87 & -1.64 \\
\hline
\end{tabular}

The gap between perception and expectation represents the quality of SERVQUAL model. The negative difference indicates that the service provided to the engineering student was less than expected. In other words, the gap between 
expectations and perceptions is where improvement is needed. The table below represents the differences between the average expectations and perceptions of each dimension.

Table 4. Quality deviations at the five dimensions

\begin{tabular}{llll}
\hline & P & E & Q \\
\hline 1 Tangibles & 4,482 & 2,455 & $-2,027$ \\
2 Reliability & 4,438 & 2,898 & $-1,540$ \\
3 Responsiveness & 4,486 & 2,593 & $-1,893$ \\
4 Assurance & 4,486 & 2,856 & $-1,630$ \\
5 Empathy & 4,618 & 2,725 & $-1,893$ \\
Average & 4,502 & 2,705 & $-1,796$ \\
\hline
\end{tabular}

The figures from Table 4 are represented in the graphs Figure 2 and Figure 3 below:

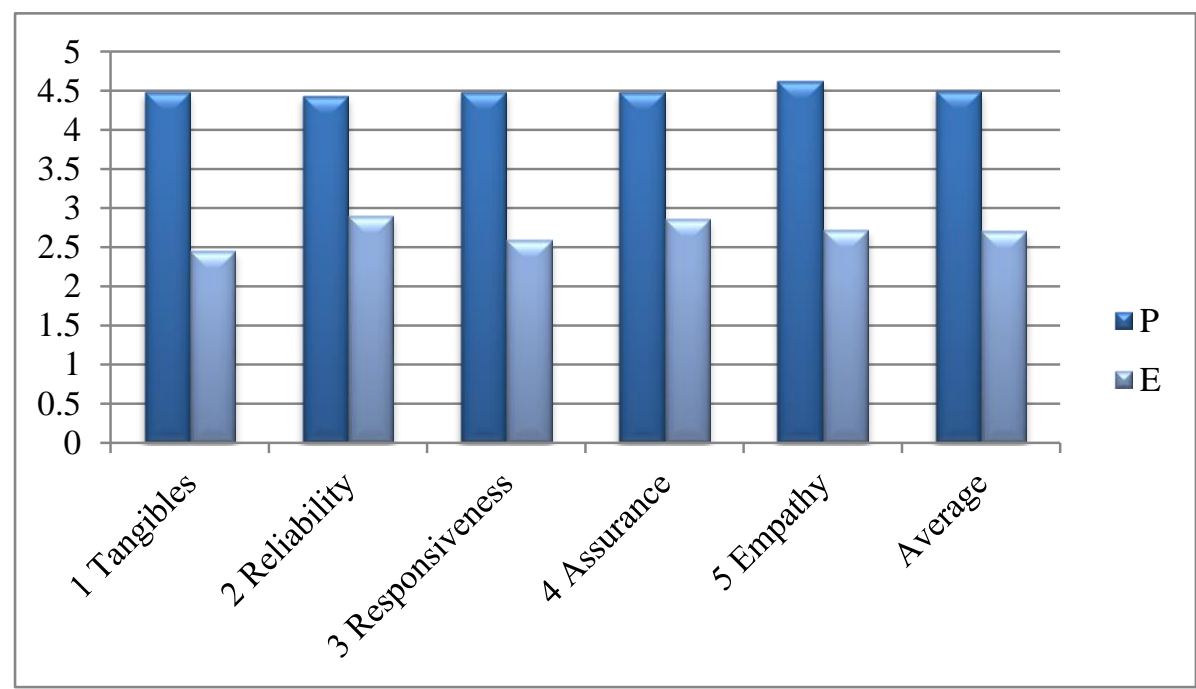

Figure 2. Gaps between perception and expectations

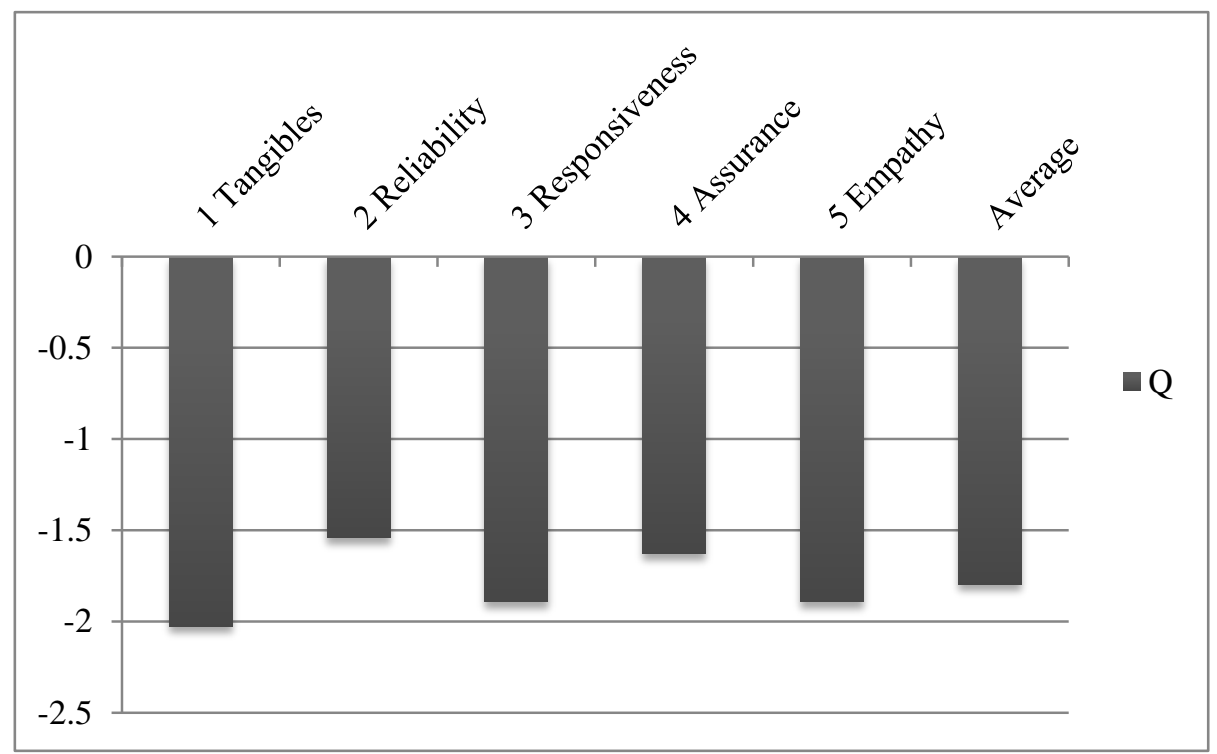

Figure 3. Quality gaps in all dimensions

Based on the figures 2 and 3, the comparison between engineering students' expectations of the service and their perception shows that the means for the five dimensions on the expectations scale are higher than the means for five dimensions on the scale of perceptions. The total difference is -1.797 , the most negative difference corresponds to 
that of the tangible elements (-2.0275), while the least negative difference corresponds to the reliability dimension $(-1.54)$.

A negative quality gap in the five dimensions was determined. Research results indicate that service quality is unsatisfactory. The most significant differences exist on the dimension of the tangibles which are represented by the appearance of the installations and physical equipment.

The next critical gaps are respectively the reactivity relating to the speed of the services and the response to the needs of the students, on the one hand. On the other hand, to the empathy linked to the behaviour of school staff towards students, the attention given to students and supports and availability.

\section{Conclusion and Suggestions}

The objective of this study is to identify factors having an important role in improving the service quality within an engineering school and thus provide a conceptual and operational framework for the decision-making by focusing on reducing non-quality gaps.

The quality of the service was assessed according to the five dimensions of the SERVQUAL model. The results of this study mainly showed that engineering students have a negative perception of the service quality.

The dimension having largest impact on student satisfaction in our study is tangible elements which were raised as the main factor influencing the satisfaction of Moroccan students as in the above-mentioned case (Cherqaoui et al., 2015.)

Consequently, the modernization of technical installations and equipment and the use of information communication technologies are essential for the development of service quality at the Moroccan engineering school.

\section{References}

Abdullah, F. (2006). The development of HEdPERF : A new measuring instrument of service quality for the higher education sector. International Journal of Consumer Studies, 30(6), 569-581. https://doi.org/10.1111/j.1470-6431.2005.00480.x

Akrim, H., Figari, G., Mottier-Lopez, L., \& Talbi, M. (2010). La place de l'évaluation dans la réforme du système éducatif marocain: Questions pour la recherche. Questions Vives. Recherches en éducation, Vol.4 $n^{\circ} 13$, 387-400. https://doi.org/10.4000/questionsvives.323

Ali, F., Zhou, Y., Hussain, K., Nair, P. K., \& Ragavan, N. A. (2016). Does higher education service quality effect student satisfaction, image and loyalty? A study of international students in Malaysian public universities. Quality Assurance in Education, 24(1), 70-94. https://doi.org/10.1108/QAE-02-2014-0008

Cherqaoui, W., Chroqui, R., \& Okar, C. (s. d.). INFLUENCE DE LA QUALITE DE L'ENSEIGNEMENT SUPERIEUR SUR LA SATISFACTION DES ETUDIANTS. 13.

Datta, K. S., \& Vardhan, J. (2017). A SERVQUAL-Based Framework for Assessing Quality of International Branch Campuses in UAE: A Management Students' Perspective. SAGE Open, 7(1), 215824401667629. https://doi.org/10.1177/2158244016676294

Direction des stratégies et des systèmes d'information "Enseignement supérieur en chiffres" 2017 / 2018.

Đonlagić, S., \& Fazlić, S. (2015). QUALITY ASSESSMENT IN HIGHER EDUCATION USING THE SERVQUAL MODEL. 20, 21.

Felix, R. (2017). Service Quality and Customer Satisfaction in Selected Banks in Rwanda. Journal of Business \& Financial Affairs, 06(01). https://doi.org/10.4172/2167-0234.1000246

Green, P. (2014). Measuring Service Quality In Higher Education: A South African Case Study. Journal of International Education Research (JIER), 10(2), 131-142. https://doi.org/10.19030/jier.v10i2.8515

Kawshalya, D. N. (s. d.). Models of Service Quality - A brief literature Review. 11.

Leisyte, L., Enders, J., \& De Boer, H. (2008). The Freedom to Set Research Agendas-Illusion and Reality of the Research Units in the Dutch Universities. Higher Education Policy, 21(3), 377-391. https://doi.org/10.1057/hep.2008.14

Mauri, A., Minazzi, R., \& Muccio, S. (2013). A Review of Literature on the Gaps Model on Service Quality: A 3-Decades Period: 1985-2013. International Business Research, 6(12), p134. https://doi.org/10.5539/ibr.v6n12p134 
Parasuraman, Zeithaml and Berry"un modèle conceptuel de qualité de service et de ses implications pour la future recherche" - journal de la chute de la vente 49 (4). 41-50.1985.

Parasuraman, Berry, et Zeithaml) - "amélioration et réévaluation de l'échelle de SERVQUAL" - journal de vendre au détail (4) l'hiver 67. 420-450, 1991.

Saravanan L. "A study of students satisfaction level towards service quality of teacher education colleges with special reference" Erode district. Shanlax International Journal of Commerce, 6(1), 52-58. 2018.

Yousapronpaiboon, K. (2014). SERVQUAL : Measuring Higher Education Service Quality in Thailand. Procedia Social and Behavioral Sciences, 116, 1088-1095. https://doi.org/10.1016/j.sbspro.2014.01.350 